\title{
THE IMPACT OF FREE TRADE BETWEEN ASEAN AND CHINA ON THE INDONESIAN HOUSEHOLDS
}

\author{
Indra Maipita \\ Fakultas Ekonomi Universitas Negeri Medan \\ Sumatera Utara, Indonesia \\ Email: imaipita@unimed.ac.id
}

\begin{abstract}
Free trade agreement between ASEAN and China was executed in early 2010. Various types of trade tariffs have been removed or lowered to support the agreement which may lead to changes in the welfare of Indonesian households. This research tries to find out the impact of ASEAN-China free trade agreement on the welfare of households in Indonesia. The model used for this analysis is AGEFIS model, a Computable General Equilibrium model of Indonesian economy. The findings of this research show that the free trade between ASEAN and China increases the level of economic activity. Various macroeconomic indicators such as output and exports increase relative to the output prior to the free trade agreement. Income of urban households rise but rural households are adversely affected. Skilled-workers benefits more than unskilled ones.
\end{abstract}

Keywords: ASEAN-CHINA Free Trade Area, AGEFIS, Shock, SAM

\section{BACKGROUND}

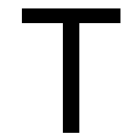

rade between countries has increased in volume in the era of free trade, where there are no barriers such as export and import tariffs (Ministry of Trade Republic of Indonesia, 2010). With the more free movement of goods and services between countries counteract reinforce possible existence of free competition. This is expected to provide low prices with high quality for all people everywhere in this world. In addition, competition is expected to provide incentives for innovation in various fields that could give rise to higher quality of various types of goods and services.

QE Journal | Vol.03 - No.02 June 2014 - 53 
Indonesia as a country with a very open economy has agreed on various free-trade agreement with many countries. The objective of Indonesia's participation in these various trade agreements is expected to increase welfare. As an ASEAN member country, Indonesia has agreed to free trade among ASEAN countries, especially for the six major countries of ASEAN (ASEAN-6), i.e., Indonesia, Malaysia, Philippines, Thailand, Singapore and Brunei Darussalam. The agreement will become effective starting date January 1, 2010 (Ministry of Finance, 2010). ASEAN Free Trade Area (AFTA) is an agreement made by the ASEAN-6 to form a free trade area of tariff barriers. The agreement was sparked at the forth ASEAN Summit of Heads of State in Singapore in 1992. The purpose of this agreement is to establish a production base area of the world, thereby creating free trade zones with regional markets for around 500 million inhabitants (Ministry of Finance, 2010).

The development of Indonesia's import from ASEAN Countries-6 and the People's Republic of China (PRC) is a trend showing an increase. Figure 1 below shows imports from ASEAN-6 countries are in the range of $13 \%$ of the total Indonesian imports and approximately 5\% of the PRC. Imports from the PRC always increase from year 2005 up to 2009. This shows the demand for goods and services from China continue to rise. Based on data from the Ministry of Trade, the trade balance between the RI-China enjoyed a surplus until the year 2007 and the deficit for the years 2008 and 2009.

Year 2010 is the beginning of the implementation of free trade with products with tariffs of $100 \%$ to $0 \%$ tariff (Ministry of Finance, 2010) among ASEAN member countries, especially ASEAN-6 who are members of AFTA. All countries who are members of the ASEAN-6 will impose tariffs of $0 \%$. ASEAN also has to agree on free trade with other countries especially with some states that are considered to have the potential to improve people's welfare through inter-state trade. Korea and China are partners with ASEAN and the increase in the economy within this free trade can be realized. 


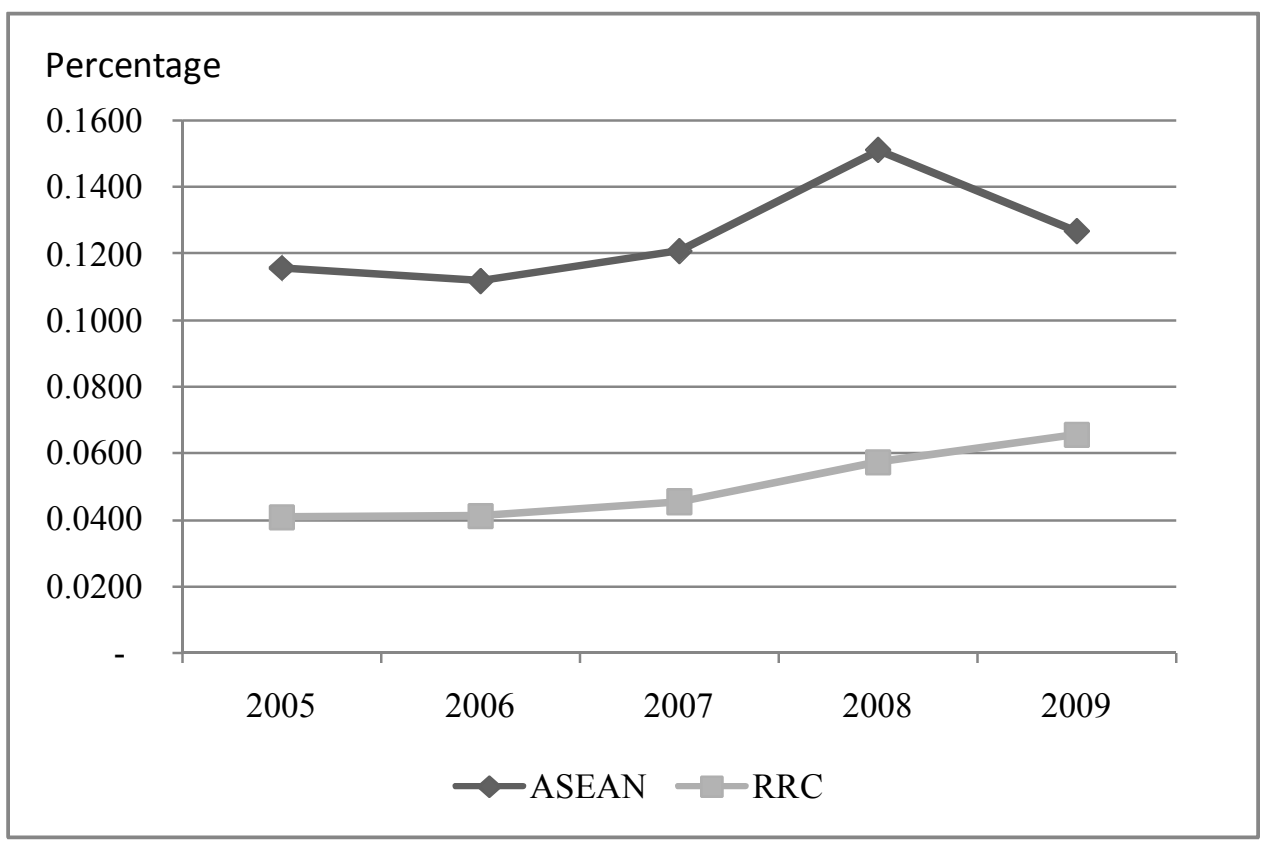

Figure 1. The percentage of Indonesian Imports from ASEAN-6 countries and RRC (Source: Ministry of Trade RI ; processed)

Free trade agreement between ASEAN and China (ASEAN China Free Trade Area - ACFTA) has been executed early in 2010. Indonesia as a member of the ASEAN countries have been consistent in implementing free trade by lowering trade tariffs on China to zero percent. Expectations of free trade with China can increase market opportunities for products made in Indonesia, for increasingly diverse range of goods, investment opportunities and high prices of goods and more competitive.

Various types of trade tariffs have been removed or lowered to support the AFTA and ACFTA agreement (Ministry of Finance, 2010). This research will try to answer the various questions surrounding the implementation of AFTA and ACFTA. Specifically this research problem formulation is as follows: (1) what is the impact of AFTA and ACFTA on various macro indicators of Indonesian economy? (2) how do labor income of various types and household welfare change as a result of the introduction of AFTA and ACFTA? 


\section{METHODOLOGY}

\section{AGEFIS Model}

AGEFIS (Applied General Equilibrium model for FIScal Policy Analysis) is a Computable General Equilibrium (CGE) model designed specifically, but not limited, to analyze various aspects of fiscal policies in Indonesia. AGEFIS was built under the capacity building activity carried out by the CGE Modeling Unit (CCMU), Center for Economics and Development Studies (CEDS), Faculty of Economics, Padjadjaran University, for Fiscal Policy Agency, The Ministry of Finance, Republic of Indonesia. It was developed to anticipate the need of the Ministry of Finance to analyze the impact of various fiscal policies on the economy, as well as the impact of various economic shocks to the fiscal position of the budget of the Indonesian government. The Data used in this research is largely on secondary data, i.e., Social Accounting Matrix (SAM) of Indonesia in 2005 from the Indonesia Statistics. AGEFIS is basically a SAM-based CGE model solved by Gempack (Yusuf, 2008). Detail structure of the first AGEFIS model can be found in Yusuf et al (2008). Specific for this research, the AGEFIS model described in Yusuf et al (2008) is extended to have several households types and changing its database with more detailed sector and labor type as available in the SAM 2005.

\section{Model Structure}

Primary production factor used is labor (labor) and capital (capital). Production structure of the 24 sectors of the economy using a nested Leontief production function for intermediate inputs, while the valueadded production function has the specification of the CES (constant elasticity of substitution).

- Optimization of the composition of imports and domestic goods carried by a single actor (agent) economy with the Armington specification.

- Household sector will maximize its utility function following the Cobb-Douglas utility functions.

- Households earn income from the ownership of factors of production as well as transfers from governments, businesses and overseas. 
- The government earns revenue from indirect taxes, direct tax, ownership and transfer factor from other institutions such as overseas.

- Government to spend its budget for consumption, commodity subsidies, and transfers to other institutions, like the household.

Closure model is flexible, such as: (a) long-term closure is full employment of factors and mobile capital and labor Between sectors. (B) short-term closures of the first is the capital could not move to other sectors, while aggregate employment can be altered so that unemployment can occur. Short-term closures of both the capital could not move the labor sector, but the assumption is always in a state of full employment.

\section{Production Structure Model}

The principle activities of any industry is to transform input to output. Each producer (represented by the activity) is assumed to maximize profits. Profit maximization with the constraints of the production technology is shown in the following chart.

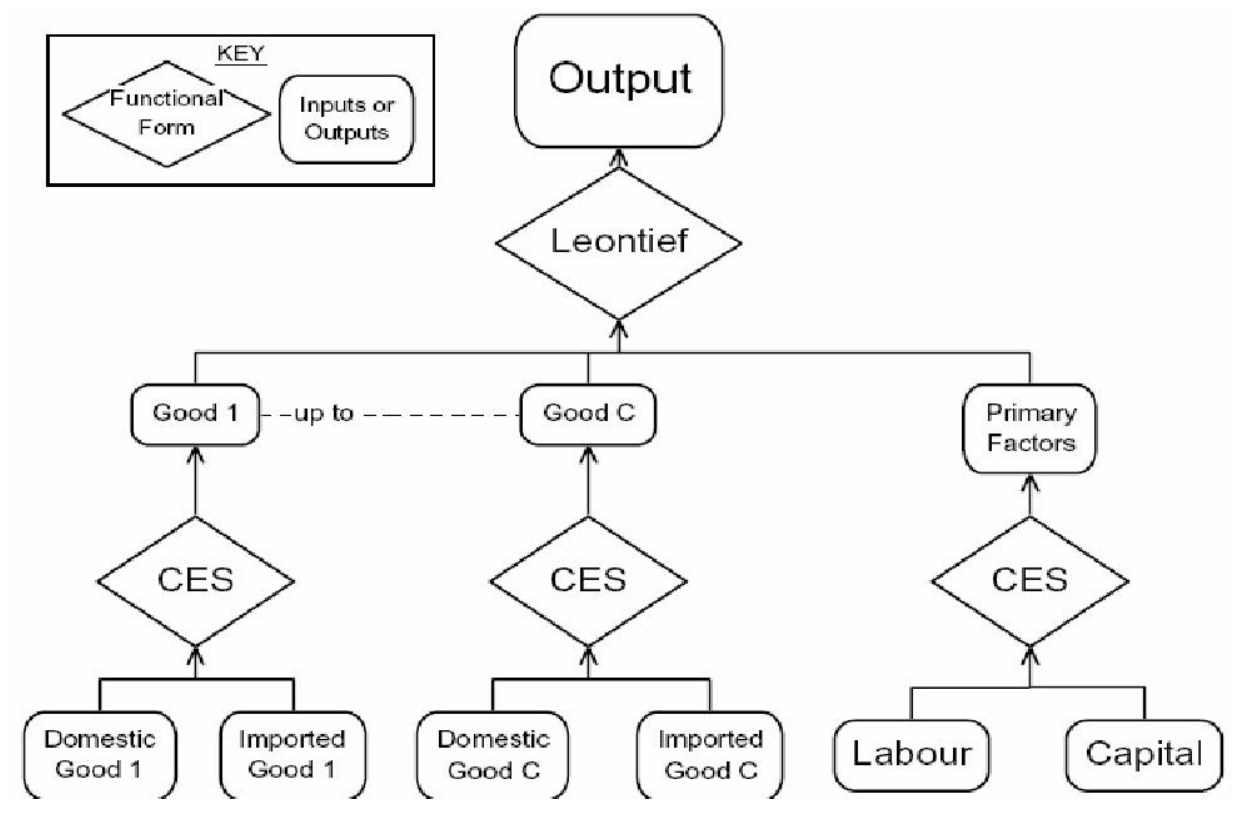

(Sources: BKFDK-RI, 2008; Yusuf et al, 2007; Maipita et al,2012)

Figure 2. Production Structure 
Input to output relationship using the CES-Leontief production function at each production sector. Demand for production factors are translated into several sections, namely: (1) primary factor demand by each industry-i, (2) the price of primary factor composite, (3) industrial demand for primary factor composite, and (4) the value of the demand for production factors.

As shown in Figure 2, the input of production in this model is divided into two parts, the input of the composite primary input consisting of labor (labor) and capital (capital) as well as input from intermediate goods (intermediate goods) is also a composite of domestic and import.

Exhibit 1 in the first level, the determination of input from intermediate goods and production factors aggregated by the CES function (Constant Elasticity of Substitution). Thus the primary factor composite is a function of each industry aggregate CES. So written that:

$$
\text { primary factor composite }=\text { CES(Labour, Capital })
$$

Similarly, the intermediate goods (composite goods) is a function of aggregate from the CES, which is written:

$$
\text { Composite good }(i)=\text { CES[domestic good( } i) \text {, imported good(i)] }
$$

At the second level, primary factors and composite goods combined to produce output using a production function of Leontief (fixed proportions technology). Because this model assumes that the output is a function of the composite primary factors and composite goods, it can be written that:

Output $=f($ input $)=f($ labor, capital, domestic goods, imported goods)

$$
=f \text { (primary factor comosite, composite goods) }
$$

Consequences from the use of CES-Leontief function is that all requests for input will have a direct proportion to the output.

\section{Structure Demand Model}

In this model, institutions are assumed to be maximizing its utility by finding the optimum combination of goods consumed in accordance with the existing budget. Institutions will maximize his utility with the CESaggregator function Cobb-Douglas as shown in figure 3. To maximize its utility, the institution took two stages. The first (top level), the institution will determine the choice of composite goods are to use an aggregator function of the Cobb-Douglas. Second (lower level), the institution will

$$
\text { QE Journal | Vol.03 - No.02 June } 2014 \text { - } 58
$$


determine the choice of composite goods from domestic production or imports.

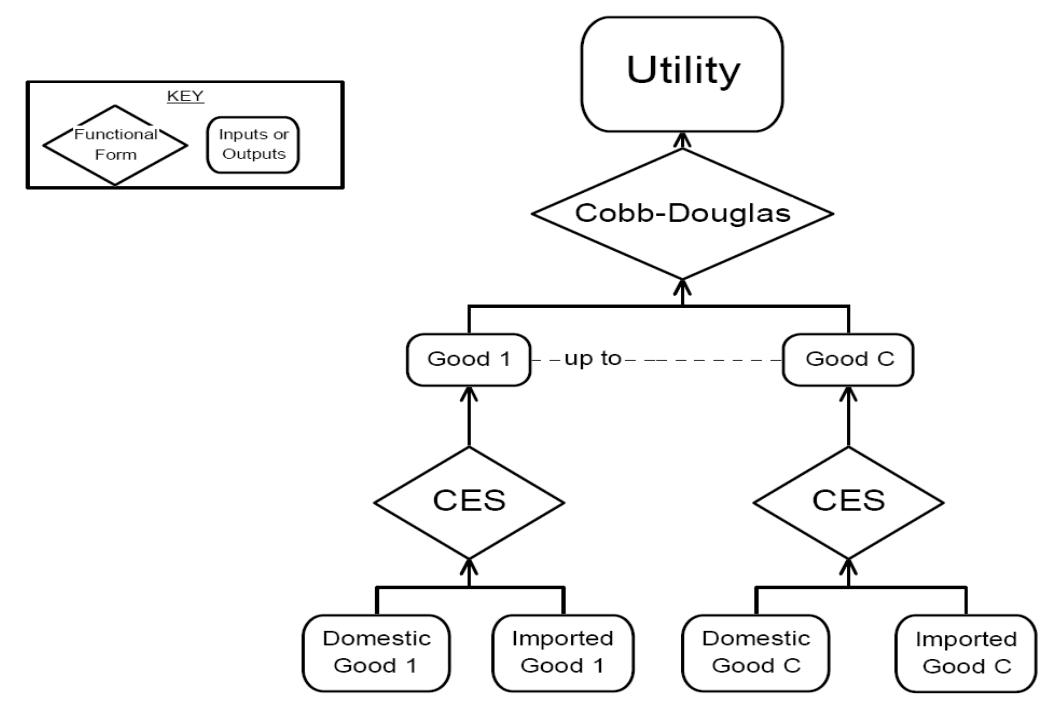

(Sources: BKFDK-RI, 2008; Maipita et al, 2012)

Figure 3. Demand Structure

Institutions in this model consists of three types, namely households, industry and government. While the demand for composite goods consisting of four types, namely: (1) the demand for investment goods (demand for the commodity for investment), (2) the demand for goods by industry (demand for the commodity by the industry), (3) demand for goods by households (demand for the commodity by household) and (4) demand for goods by the government (demand for the commodity by government). The structure of demand for goods is abstracted in Figure 4. 


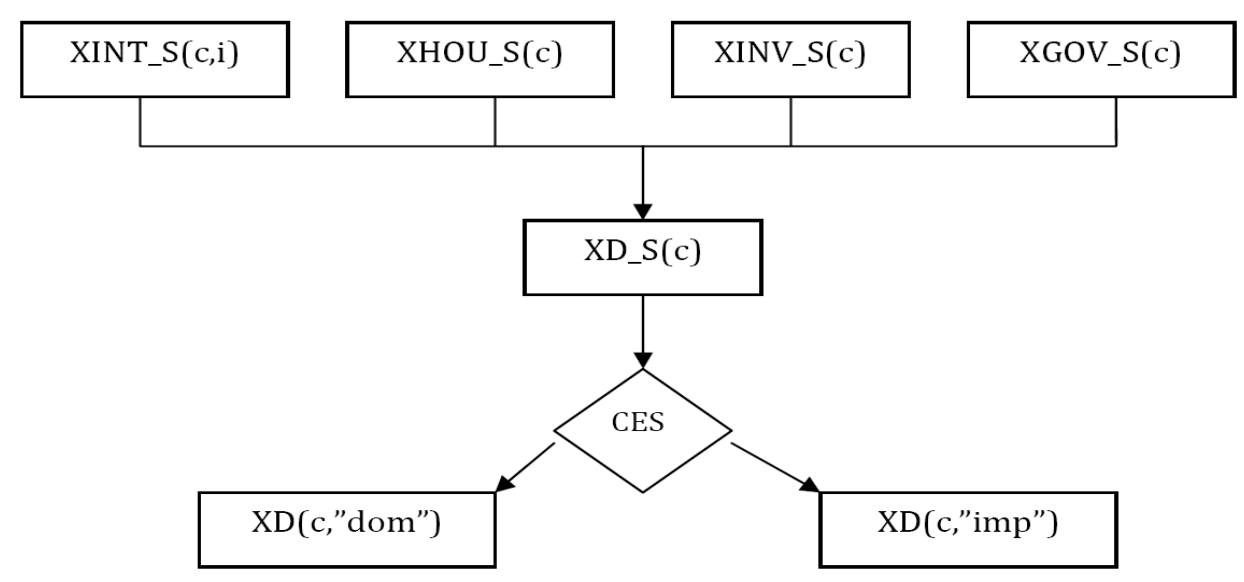

(Sources: BKFDK-RI, 2008; Yusuf et al, 2007)

Figure 4. Demand for Composite Goods

\section{Closure}

There are two models used the standard closure nature of this model, which is standard short run closure and standard long-run closure. Difference between the two lies in the factor market closure. In the short run closure, capital is specific to where he can not move between sectors. In other words, into a fixed capital input for each industry. This can be done by creating a demand variable capital (xfac ("capital", IND)) in all industries are exogenous variables and make the price distortion factor for the capital (wdist ("capital, IND)) is not in the closure model (which exists only for labor (wdist ("labor:, IND))). In addition, the aggregate amount of labor for the labor market can change. This can be done by making the total variable factor supply for labor (xfacsup ("labor")) as an endogenous variable and make the price of labor (pfac ("labor") to the exogenous variables. In other words, it is assumed that there is a nominal wage rigidity in the economy.

\section{Simulations}

The Impact of Free Trade between ASEAN and China on the welfare of the Indonesian Household using a CGE models called AGEFIS.

Simulation carried out in this study consists of two scenarios. Referring to a recent research conducted by Sadewa (2010), the scenarios will be as follows: (1)The first scenario assumes that Indonesia is involved in the two free trade agreements with AFTA and ACFTA and imposed an entrance fee

QE Journal | Vol.03 - No.02 June 2014 - 60 
$0 \%$ for all commodities between countries of ASEAN-6 and China; (2) The second scenario, assume that Indonesia is only involved in free trade with ASEAN or AFTA and import tariffs among ASEAN-6 is $0 \%$.

Base on the import tarif in Indonesian Data Base and multiply with the rasio import from China or ASEAN to all Indonesian's import, we get the number of tarif to reduce and make the zero import tarif for China and ASEAN country.

The shocks of each scenario that will apply in AGEFIS CGE Model are shown in table 1 below:

Table 1. The scenarios of the Impact of Free Trade between ASEAN and China on the welfare of the Indonesian Households (\%)

\begin{tabular}{|c|c|}
\hline io I (China and ASEAN) & Scenario II (ASEAN) \\
\hline $\begin{array}{l}\text { shock delTM("CROPS")=-0.04647; } \\
\text { shock delTM("OTHCRP" })=-0.08117 ; \\
\text { shock delTM("LIVSTK")=-0.05027; } \\
\text { shock delTM("FOREST")=-0.02227; } \\
\text { shock delTM("FISH")=-0.02529; } \\
\text { shock delTM("MINE")=-0.00182; } \\
\text { shock delTM("OTHMINE")=- }\end{array}$ & $\begin{array}{l}\text { shock delTM }\left(" C R O P S^{\prime \prime}\right)=-0.03333 ; \\
\text { shock delTM }\left(" O T H C R P^{\prime \prime}\right)=-0.05821 ; \\
\text { shock delTM }\left(" L I V S T K^{\prime \prime}\right)=-0.03605 ; \\
\text { shock delTM }\left(" F O R E S T^{\prime \prime}\right)=-0.01597 ; \\
\text { shock delTM }\left(" F I S H^{\prime \prime}\right)=-0.01814 ; \\
\text { shock delTM }\left(" M I N E^{\prime \prime}\right)=-0.0013 ; \\
\text { shock delTM }\left(" O T H M I N E^{\prime \prime}\right)=-\end{array}$ \\
\hline $\begin{array}{l}0.05761 ; \\
\text { shock delTM("FOOD")=-0.04; } \\
\text { shock delTM("TEXTILE")=-0.07254; } \\
\text { shock delTM("WOODP")=-0.02255; } \\
\text { shock delTM("PAPER")=-0.04341; } \\
\text { shock delTM("CHEM")=-0.03001; }\end{array}$ & $\begin{array}{l}0.04132 ; \\
\text { shock delTM }\left(" F O O D^{\prime \prime}\right)=-0.02869 ; \\
\text { shock delTM }\left(" T E X T I L E^{\prime \prime}\right)=-0.05202 ; \\
\text { shock delTM }\left(" W O O D P^{\prime \prime}\right)=-0.01617 ; \\
\text { shock delTM }\left(" P A P E R^{\prime \prime}\right)=-0.03113 ; \\
\text { shock delTM }\left(" C H E M^{\prime \prime}\right)=-0.02153 ;\end{array}$ \\
\hline
\end{tabular}

\section{RESULT AND DISCUSSIONS}

The simulation results performed using AGEFIS model shows that exports for all sector has increased in both scenarios. The sector which experiences the highest increase is pulp and paper industry, followed by agriculture and textile industries. It should be noted that those sectors are mainly labor intensive.

The increase in exports is generally higher in the first scenario than the second scenario. The more free trade zones are involved, the higher the increase in Indonesian exports. This indicates that with the involvement of 
Indonesia into a free trade area, at least for the ASEAN and the PRC, Indonesia's international trade tends to rise.

Table 2. Simulated Impact on Indonesian Export (Percentage Change relative to baseline)

\begin{tabular}{lcclcc}
\hline \multicolumn{1}{c}{ Output } & Scenario I & Scenario II & Output & Scenario I & Scenario II \\
\hline CROPS & 3.26 & 2.31 & ELECTR & 2.24 & 1.60 \\
OTHCRP & 3.15 & 2.22 & CONSTRU & 3.88 & 2.75 \\
LIVSTK & 2.39 & 1.69 & TRADE & 0.13 & 0.10 \\
FOREST & 1.56 & 1.11 & RESTAU & 1.61 & 1.14 \\
FISH & 1.36 & 0.97 & HOTEL & 1.10 & 0.78 \\
MINE & 0.30 & 0.22 & LNDTRAN & 2.40 & 1.71 \\
OTHMINE & 0.92 & 0.66 & AIRTRAN & 1.68 & 1.20 \\
FOOD & 2.28 & 1.62 & WTRTRAN & 0.74 & 0.53 \\
TEXTILE & 3.20 & 2.27 & BANK & 0.11 & 0.08 \\
WOODP & 1.40 & 1.00 & ESTATE & 0.78 & 0.56 \\
PAPER & 4.18 & 2.97 & GOVSER & 0.69 & 0.50 \\
CHEM & 1.36 & 0.97 & OTHSER & 3.37 & 2.39 \\
\hline
\end{tabular}

The impact on factor income is shown in Table 3. Income of almost all unskilled labor declines (except unskilled informal urban labor). On the other hand, income of almost all skilled labor has increased. The magnitude of this impact is higher with scenario I compared to scenario II.

As shown in Table 4, rural households, especially those dependent on agriculture, experience lower income while urban households experience higher income as a result of the simulations. This may indicate that the impact of the free trade of both AFTA and ACFTA benefit only urban households. Looking at the table 5 (percentage change in output), this is more or less explained by the contraction of the output of agriculture and extractive sectors.

Looking at Table 5 in more detail, it describes how the impact of AFTA frees trade and ACFTA on output of each sector in the economy. The output of textile industry increases by $1 \%$ in the first scenario and by $0.7 \%$ in the second scenario. Only seven of 24 experience a decrease in output. 
Table 3. Percentage Changes in Factor Income

\begin{tabular}{llllrl}
\hline & & & Type & Scenario I & Scenario II \\
\hline UnSkilled & Formal & Rural & LAB01 & -0.7079 & -0.5011 \\
Unskilled & Informal & Urban & LAB02 & -0.4849 & -0.3430 \\
Unskilled & Formal & Rural & LAB03 & -0.7905 & -0.5607 \\
Unskilled & Informal & Urban & LAB04 & -0.6057 & -0.4297 \\
Unskilled & Formal & Rural & LAB05 & -0.0371 & -0.0277 \\
Unskilled & Informal & Urban & LAB06 & -0.0045 & -0.0053 \\
Unskilled & Formal & Rural & LAB07 & -0.1233 & -0.0895 \\
Unskilled & Informal & Urban & LAB08 & 0.1119 & 0.0784 \\
Skilled & Formal & Rural & LAB09 & 0.3084 & 0.2191 \\
Skilled & Informal & Urban & LAB10 & 0.3154 & 0.2237 \\
Skilled & Formal & Rural & LAB11 & 0.2590 & 0.1834 \\
Skilled & Informal & Urban & LAB12 & 0.2996 & 0.2123 \\
Skilled & Formal & Rural & LAB13 & 0.3696 & 0.2635 \\
Skilled & Informal & Urban & LAB14 & 0.2929 & 0.2084 \\
Skilled & Formal & Rural & LAB15 & -0.1893 & -0.1345 \\
Skilled & Informal & Urban & LAB16 & 0.1525 & 0.1072 \\
& & & Capital & 0.0199 & 0.0134 \\
\hline & & & &
\end{tabular}

Table 4. Percentage Changes in Household Income

\begin{tabular}{cllrr}
\hline & & Income & \multicolumn{1}{c}{ Scenario I } & \multicolumn{1}{c}{ Scenario II } \\
\hline Agriculture & Worker & HH01 & -0.3662 & -0.2607 \\
& Agricultural & HH02 & -0.3693 & -0.2627 \\
& entrepreneur & HH03 & -0.2391 & -0.1703 \\
& & HH04 & -0.1915 & -0.1363 \\
Non & Rural & HH05 & -0.1098 & -0.0788 \\
Agriculture & & HH06 & -0.2800 & -0.1994 \\
& & HH07 & -0.0951 & -0.0679 \\
& \multirow{2}{*}{ Urban } & HH08 & 0.0323 & 0.0217 \\
& & HH09 & 0.0926 & 0.0648 \\
& & HH10 & 0.1810 & 0.1281 \\
\hline
\end{tabular}

Source: Simulation Results AGEFIS

QE Journal | Vol.03 - No.02 June 2014 - 63 
Table 5. Percentage Changes in Output

\begin{tabular}{lrrlrr}
\hline \multicolumn{1}{c}{ Output } & Scenario I & Scenario II & Output & Scenario I & Scenario II \\
\hline CROPS & -0.0382 & -0.0277 & ELECTR & 0.1886 & 0.1341 \\
OTHCRP & -0.4693 & -0.3300 & CONSTRU & 0.0021 & 0.0016 \\
LIVSTK & 0.1808 & 0.1283 & TRADE & -0.0203 & -0.0145 \\
FOREST & 0.3316 & 0.2365 & RESTAU & 0.3060 & 0.2173 \\
FISH & 0.2549 & 0.1809 & HOTEL & 0.7387 & 0.5264 \\
MINE & -0.0719 & -0.0490 & LNDTRAN & 0.0640 & 0.0455 \\
OTHMINE & -0.8854 & -0.6271 & AIRTRAN & 0.5019 & 0.3584 \\
FOOD & 0.2387 & 0.1692 & WTRTRAN & 0.3060 & 0.2195 \\
TEXTILE & 1.0308 & 0.7337 & BANK & 0.0288 & 0.0208 \\
WOODP & 0.6688 & 0.4782 & ESTATE & 0.1724 & 0.1236 \\
PAPER & -0.3642 & -0.2624 & GOVSER & 0.0976 & 0.0700 \\
CHEM & -0.6277 & -0.4482 & OTHSER & 0.3784 & 0.2698 \\
\hline
\end{tabular}

Source: Simulation Results AGEFIS

From macroeconomic perspective, with the introduction of free trade, real GDP rise slightly in both scenarios indicating efficiency gain from trade. The price level decreases (both consumers price and export price) and welfare as indicated by real consumption increases.

Table 6. Percentage Changes in Macroeconomic Variables

\begin{tabular}{llrr}
\hline Description & Macros & Skenario I & Skenario II \\
\hline Consumers price index & cpi & -0.7494 & -0.5341 \\
Price of consumption & pcon_c & -0.7494 & -0.5341 \\
Price of export & pexp_c & -0.3766 & -0.2689 \\
Real consumption & xcon_c & 0.6809 & 0.4837 \\
Real export & xexp_c & 1.9043 & 1.3554 \\
Real gdp- expenditure side & xgdpexp & 0.0996 & 0.0750 \\
Real import & ximp_c & 3.4536 & 2.4451 \\
\hline
\end{tabular}

Government experiences a budget deficit in both scenarios. This is mainly caused by the fall in tariff revenue. 
Table 7. Change in Government Budget (Billion Rp)

\begin{tabular}{|c|c|c|c|c|}
\hline \multirow[t]{2}{*}{ delBUDGET } & \multicolumn{2}{|c|}{ REVENUE } & \multicolumn{2}{|c|}{ EXPENDITURE } \\
\hline & Scenario 1 & Scenario 2 & Scenario 1 & Scenario 2 \\
\hline INDTAX & -369.21 & -263.99 & 0.00 & 0.00 \\
\hline TARIFF & $-23,804.43$ & $-16,827.83$ & 0.00 & 0.00 \\
\hline HHINCTAX & -28.55 & -20.72 & 0.00 & 0.00 \\
\hline CORPTAX & 59.00 & 39.82 & 0.00 & 0.00 \\
\hline TRANGOV & -744.14 & -530.33 & -744.14 & -530.33 \\
\hline FOREIGN & -9.60 & -6.84 & -106.08 & -75.60 \\
\hline FACTOR & 3.17 & 2.14 & 0.00 & 0.00 \\
\hline CONS & 0.00 & 0.00 & -546.96 & -391.14 \\
\hline SUBSIDY & 0.00 & 0.00 & -524.77 & -375.29 \\
\hline TRANHH & 0.00 & 0.00 & $-1,052.10$ & -749.81 \\
\hline SAVING & 0.00 & 0.00 & $-21,919.70$ & $-15,485.58$ \\
\hline TOTAL & $-24,893.77$ & $-17,607.75$ & $-24,893.76$ & $-17,607.75$ \\
\hline
\end{tabular}

Source: Simulation Results AGEFIS

\section{CONCLUDING REMARKS}

The main objective of this paper is to evaluate the effect of ASEAN-China Free Trade Agreement on household welfare in Indonesia. To this end, we constructed a general equilibrium model for Indonesian economy that mimics AGEFIS structure to find the impacts to household's welfare, economic growth and government budget.

This research shows the level of economic changes better than not involved in free trade zones ACFTA and AFTA. Macro indicators, output and exports showed a good level of percentage change and stimulate the economy to higher ground.

Household welfare as viewed by the income of households in urban areas are still growing. The rest of household that work in agriculture and nonagriculture in rural are hurt by this policy. For the factors of production, skilled workforce has a positive benefits then the uneducated workers. This is a recommendation for the government to improve education and training systems for unskilled labor force.

QE Journal | Vol.03 - No.02 June 2014 - 65 


\section{REFERENCES}

Abimanyu, Anggito. 2000. Impact of Agriculture Trade and Subsidy Policy on the Macroeconomy, Distribution, and Environment in Indonesia: A Strategy for Future Industrial Development. Developing Economies, 38(4): 547-571.

BKFDK-RI (Board of Fiscal Policy Department of Finance of the Republic of Indonesia). 2008. The Development of Computable General Equilibrium Model: Training Module Session I, Center for Economics and Development Studies (CEDS), Faculty of Economics, University of Padjajaran Bandung.

Dervis, K., J. de Melo and S. Robinson. 1982. General Equilibrium Models for Development Policy, Cambridge University Press, Cambridge, England.

Ghadimi, Hodjat. 2007. Computable General Equilibrium (CGE) Models: A Short Course, Regional Research Institute Regional Research Institute, www.rri.wvu.edu

Hartono, Djoni, Dominicus Savio Priyarsono, Tien Dung Nguyen, and Mitsuo Ezaki. 2007. Regional Economic Integration and Its Impacts on Growth, Poverty, and Income Distribution: the Case of Indonesia, Review of Urban and Development Studies, 19(2): 138-153.

Lewis, Jeffrey D. 1991. A Computable General Equilibrium (CGE) Model of Indonesia. HIID Series of Development Discussion Papers No. 378.

Maipita, Indra., Wawan H., Fitrawaty (2012). Reducing Poverty Trough Subsidies: Simulation of Fuel Subsidy Divertion to Non-Food Crops. Buletin Ekonomi Moneter dan Perbankan Bank Indonesia, 14(4): 369-387.

Oktaviani, R., D. Hakim, S. Sahara, and H. Siregar. 2007. The Impact of a Lower Oil Subsidy on Indonesian Macroeconomic Performance, Agricultural Sector and Poverty Incidences: A Recursive Dynamic Computable General Equilibrium Analysis, MPIA Working Paper 2007-28, Poverty and Economic Policy, http://www.pep-net.org/

Sadewa, Purbaya Yudhi. 2010. Sebaiknya Tidak Ikut FTA ASEAN-China? Reksadana-research.com.

Yusuf, Arief A. and Budy P. Resosudarmo. 2007. On the Distributional Effect of Carbon Tax in Developing Countries: The Case of Indonesia", Papers No. EEN0706, Economics and Environment Network, the Australian National University.

QE Journal | Vol.03 - No.02 June 2014 - 66 
Yusuf, Arief Anshory, Hartono, Djoni, Hermawan, Wawan and Yayan. 2008. AGEFIS:Applied General Equilibrium for FIScal Policy Analysis, No 200807, Working Papers in Economics and Development Studies (WoPEDS), Department of Economics, Padjadjaran University, http://econpapers.repec.org/RePEc:unp:wpaper:200807.

Yusuf, A. A., Hartono Djoni, and Wawan Hermawan, Y. 2007. AGEFIS: Applied General Equilibrium for Fiscal Policy Analysis. Working Paper in Economics and Development Studies No. 200807. Department of Economics, University of Padjadjaran. 